\title{
Author Correction: Increased burden of ultra-rare structural variants localizing to boundaries of topologically associated domains in schizophrenia
}

\author{
Matthew Halvorsen, Ruth Huh, Nikolay Oskolkov (1D, Jia Wen (1), Sergiu Netotea, Paola Giusti-Rodriguez (D), \\ Robert Karlsson (1), Julien Bryois, Björn Nystedt (1), Adam Ameur (1), Anna K. Kähler, NaEshia Ancalade, \\ Martilias Farrell (1), James J. Crowley, Yun Li, Patrik K. E. Magnusson (1D, Ulf Gyllensten, Christina M. Hultman, \\ Patrick F. Sullivan \& Jin P. Szatkiewicz (D)
}

Correction to: Nature Communications https://doi.org/10.1038/s41467-020-15707-w, published online 15 April 2020.

In this article, the grant number NIMH K01 MH109772 relating to the National Institute of Mental Health for Paola Giusti-Rodriguez was omitted. The original article has been corrected.

Published online: 05 January 2022

\begin{abstract}
(c) (i) Open Access This article is licensed under a Creative Commons Attribution 4.0 International License, which permits use, sharing, adaptation, distribution and reproduction in any medium or format, as long as you give appropriate credit to the original author(s) and the source, provide a link to the Creative Commons license, and indicate if changes were made. The images or other third party material in this article are included in the article's Creative Commons license, unless indicated otherwise in a credit line to the material. If material is not included in the article's Creative Commons license and your intended use is not permitted by statutory regulation or exceeds the permitted use, you will need to obtain permission directly from the copyright holder. To view a copy of this license, visit http://creativecommons.org/licenses/by/4.0/.
\end{abstract}

(C) The Author(s) 2022 